and use of physicists in the Army and Navy only for work requiring their training. The Committee states that there is not sufficient understanding of the importance of physics in the war effort, especially on the part of the general public and of some local boards of the Selective Service. To remedy this, it is suggested that a public relations programme be commenced to educate the general public to the position, and to impress on students and teachers of physics the importance of continuing their work.

\section{Control of Opium and Other Dangerous Drugs}

MeErings in connexion with the international control in narcotics have just been held in London under the International Conventions concluded in 1925 and 1931. The Permanent Central Opium Board, which exercises, under the auspices of the League of Nations, the supervision over the manufacture of, and trade in, opium and other dangerous drugs in all parts of the world, has held its forty-first session. It was attended by Sir Atul Chatterjee, president (India), Mr. Herbert L. May, vice-president (United States of America), Sir Malcolm Delevingne (United Kingdom), Mr. J. H. Delgorge (The Netherlands), and Dr. George Woo (China). The Board carefully scrutinized the world position as it appears from the statistical reports sent in for the year 1941 by fifty sovereign States and some sixty-six dependencies and colonies and other territories. It also considered certain questions of policy and solutions of problems arising from the special circumstances of the War. Under the terms of the Conventions, the Board's report on its work is being sent to the Secretary General of the League of Nations.

The other intermational organization operating under the Conventions, namely, the Supervisory Body, has the task of examining annual estimates sent by Governments of their drug requirements, and members of it met for consultations to consider questions arising on the estimates for 1943, and issuing the Supervisory Body's annual statement on world requirements of narcotic drugs for that year.

\section{Collaboration in the British Empire}

The Peter Le Neve Foster Lecture on "Empire Relations", delivered by Viscount Bennett before the Royal Society of Arts on June 3 (J. Roy. Soc. Arts, $90,613 ; 1942)$, gives a lucid survey of the development of the relations between the parts of the British Empire from the sixteenth century to the organiza. tion of the present Imperial Conference system in 1907, when these conferences became a fixed method of consultation between the self-governing Colonies and Great Britain and one another. Mainly from a constitutional point of view, Lord Bennett gives an account of the further development of the system and its limitations, notably its failure effectively to promote Imperial development on scientific lines. Imperial conferences since 1907 have been concerned with almost every conceivable subject, including communications, patents, development of Empire resources, research, timber reserves, wool production, etc., but while they have afforded an opportunity for representatives of all the nations of the Commonwealth to meet one another and discuss personally Empire problems in the light of their experience and special knowledge of their own communities, they have led to no agreement upon any adequate method for providing continuous consultation on matters of common concern. Urging the need for an earnest effort to make the story of the Empire better known to the youth of Great Britain, Lord Bennett stresses the importance of providing the means for adequate and continuous consultation. This is essential for common action by the Governments of the Empire to attain a common end, and he suggests that a member of each of the Governments of the Overseas Dominions might be resident in London. Regular meetings between the Prime Ministers or representatives of their several Governments, utilizing air transport and with a permanent secretariat, might provide a solution of the problem.

\section{A Proposed World Calendar}

THz World Calendar Association, Inc., New York, has published details for a proposed new calendar to commence in 1945 ("The World Calendar-A New Calendar for a New World." Pp. 32. World Calendar Association, Inc., 630 Fifth Avenue, New York). On the basis of a 364-day year, the year is divided into four quarters, each of 91 days. The first month of each quarter contains 31 days and each of the others 30 days, and January, April, July and October contain each 31 days. Every year and in consequence every quarter begins on a Sunday, and it is suggested that the national holidays of every country can be arranged to come on Mondays, if the people wish it, thus prodncing long week-ends. Christmas Day falls on Monday every year, and it is suggested that Easter should be the second Sunday in April, that is, April 8. As a result of fixing Easter for this date, the other movable Christian festivals, Ash Wednesday, Good Friday, Ascension Day, Whitsunday, etc., would occur on the same date every year. Such a stabiliza. tion of the hitherto movable festivals would place Advent Sunday on December 3 and Trinity Sunday on June 3-exactly six months apart. The 365th day will be at the end of December and it is recommended that it should be designated as a World Holiday by all countries accepting the new calendar. This World Holiday is an extra Saturday, called the Year-End Day. Leap Year Day is placed at the end of June, in the middle of the year, and it is also an extra Saturday and a World Holiday. The beneficial effects of the reform are explained in connexion with the various phases of life-industry, labour, Government, law, finance, science, etc. ; and an appeal is made to the citizens of different countries to lend their support to the scheme.

\section{The Problems of the A-Type Stars}

Otto Struve and P. Swings have an article with this title in the August issue of the Observatory (No. 809,64 , August, 1942). Morgan pointed out about seven years ago that there is some physical factor other than temperature and surface gravity concerned in the production of the spectra of these stars. The theory of ionization has failed to solve the problem, and the authors are convinced that existing interpretations, which are very unsatisfactory, should be abandoned. They believe that a new solution should be attempted along lines which have been forced on them by the results of their recent work on stellar shells, Wolf-Rayet stars and planetary nebulæ. It is suggestive that certain peculiarities occur in that region of the sequence of the stellar spectra where the Lyman lines and the Lyman continuous absorption cause a large redistribution of the energy in the continuous spectrum. This redistribution has a 